\title{
Reverse engineering of an aspirin-responsive regulator in bacteria
}

by

Lummy Maria Oliveira Monteiro1, Letícia Magalhães Arruda ${ }^{1}$, Ananda Sanches Medeiros ${ }^{1}$, Leonardo MartinsSantana ${ }^{1}$, Luana de Fátima Alves ${ }^{2}$, María-Eugenia Guazzaroni², Víctor de Lorenzo ${ }^{3}$ and Rafael Silva-Rocha ${ }^{1 \star}$

${ }^{1}$ Cell and Molecular Biology Department, FMRP - University of São Paulo, Ribeirão Preto, SP, Brazil

2Biology Department, FFCLRP - University of São Paulo, Ribeirão Preto, SP, Brazil

${ }^{3}$ Systems Biology Program, National Center of Biotechnology - CSIC, Madrid, Spain

Running Title: Keywords:
Engineering of an Aspirin responsive regulator in bacteria

Protein engineering, Aromatic-responsive regulator, AraC family, Aspirin, Transcriptional regulation, Synthetic Biology

${ }^{*}$ Correspondence to: Rafael Silva-Rocha

FMRP - Universidade de São Paulo

Av. Bandeirantes, 3.900. CEP: 14049-900.

Ribeirão Preto, São Paulo, Brazil

Tel.: +55163602 3107; Fax: +551636336840

E-mail: silvarochar@gmail.com 


\begin{abstract}
Bacterial transcriptional factors (TFs) and their target promoters are key devices for engineering of complex circuits in many biotechnological applications. Yet, there is a dearth of well characterized inducer-responsive TFs that could be used in the context of an animal or human host. In this work we have deciphered the inducer recognition mechanism of two AraC/XylS regulators from Pseudomonas putida (BenR and XyIS) for creating a novel expression system responsive to acetyl salicylate (i.e. Aspirin). Using protein homology modeling and molecular docking with the cognate inducer benzoate and a suite of chemical analogues, we identified the conserved binding pocket of these two proteins. Using site directed mutagenesis, we identified a single amino acid position required for efficient inducer recognition and transcriptional activation. While modification of this position in BenR abolishes protein activity, its modification in XyIS increases the response to several aromatic compounds, including acetyl salicylic acid to levels close to those achieved by the canonical inducer. Moreover, by constructing chimeric proteins with swapped $\mathrm{N}$-terminal domains, we created novel regulators with mixed promoter and inducer recognition profiles. As a result, a collection of engineered TFs was generated with enhanced response to a well characterized and largely innocuous molecule with a potential for eliciting heterologous expression of bacterial genes in animal carriers.
\end{abstract}

\title{
Introduction
}

Transcriptional regulation plays a central role in the adaptation of cells to changing in environmental conditions. In bacteria, this step is mainly regulated by the interaction of RNA Polymerase (RNAP) with the promoter region thought the use of many sigma factors, and by a large number of transcriptional factors (TFs) that can help or block RNAP binding1. With the growing interest into the engineering of living cells for novel biotechnological and biomedical application, a special focus has emerged in understanding gene regulation at the molecular level $1,2,3$, ${ }^{4}$. In this context, many different classes of TFs have been extensively characterized at the molecular detail from bacteria to mammals and this knowledge has allowed a number of engineering projects, where natural systems can be repurposed to display novel behaviors $1,5,6,7,8,9$. Attempts in this direction are very diverse and examples are the construction of mutated variant of natural TFs with enhanced or modified performance $10,11,12,13$, the recombination of protein domains to create TFs with completely altered specificity or dynamical behavior ${ }^{14,15}$ or the mining of novel regulators from genomes or metagenomes ${ }^{16,17}$. Additionally, the revolution provided by CRISPR/Cas9 system has also impacted the field of gene regulation, as this system has been repurposed to construct fully synthetic expression systems based on RNA/DNA interaction 18, 19, 20.

Despite the progress on the engineering of novel expression systems, a critical bottleneck relies on the selection of suitable signal-recognition modules related to the application of interest. In other words, while many different TFs are well-characterized as responsive to small molecules (sugars, ions, aromatics, etc.), many times the application at stake requires systems responsive to unusual compounds ${ }^{21}$. Therefore, construction of TFs variants with enhanced responsivenes to non-natural ligands has become more appealing. Approaches to accomplish this task range from the use of laborious random mutagenesis followed by selection ${ }^{11,12}$ to the use of computational analysis to guide rational design ${ }^{22}$. Here, we focused on the engineering of novel expression systems responsive to commercially available drugs suitable to in vivo administration to a mammalian animal. Our particular interest was focused on acetylsalicylic acid (ASA or aspirin), a longstanding, safe and widely used drug. This compound has been applied in synthetic regulatory circuits to deliver lytic proteins to tumors in vivo, representing a promising field for the development of tumor-targeting circuits for clinical applications ${ }^{23}$. As a starting point, we sought to investigate the molecular mechanisms of signal recognition by two homologous regulators of Pseudomonas putida, namely BenR and XyIS. These two TFs are members of the AraC/XyIS family of transcriptional activators $24,25,26$ that recognize different aromatic compounds with structural similarities to ASA. Yet, while both regulators share around $60 \%$ amino acid (aa) identity, BenR is responsive to benzoate-only 25 while XylS can recognize a large number of substituted variants ${ }^{27}$. Additionally, some crosstalk between these two regulators and their target promoters has been characterized, as XylS can only recognize its target $P m^{24}$ while BenR can efficiently activate its natural target $P b$ as well as $P m^{25}$.

In this we have investigated the molecular mechanisms of signal recognition by these two regulators using computational tools and in vivo validation. By constructing a model for the ligand-binding domain of BenR and 
bioRxiv preprint doi: https://doi.org/10.1101/400788; this version posted August 27, 2018. The copyright holder for this preprint (which was not certified by peer review) is the author/funder, who has granted bioRxiv a license to display the preprint in perpetuity. It is made available under aCC-BY-NC-ND 4.0 International license.

performing molecular docking with benzoate and a collection of analogues, we identified a potential binding pocket strongly conserved between these two TFs. Thereby, we were able to validate the pocket using site directed mutagenesis and also by constructing chimeric proteins. Finally, we demonstrated how a single aa position plays a critical and opposite role in the activity of both proteins. Some changes of this position in BenR resulted in complete loss of protein activity while the same in XyIS triggered an enhanced response to benzoate analogues, including ASA. The results below thus provide not only insights on the mechanism of signal recognition by members of the AraC/XylS family but also the engineering of a regulatory device responsive to aspirin.

\section{Results}

\section{Analysis of conserved elements in BenR and XylS close homologues and target promoters}

In order to investigate the molecular mechanisms accounting for the functional differences between BenR and XylS, we analyzed the close homologues of these proteins existing the genome of some species of Pseudomonas. As represented schematically in Fig. 1, these proteins are TFs formed by two domains, one Nterminal (AraC domain) which is required for ligand recognition ${ }^{28}$ and one C-terminal domain composed by two helix turn helix $(\mathrm{HTH})$ regions required for the recognition of the distal and proximal operators (Od and Op) upstream of the target promoters ${ }^{25,29}$. It is proposed that two monomers of XyIS are required for the activation of the $P m$ promoter, each binding to an operator region and contacting an $\mathrm{A}$ and $\mathrm{B}$ box conserved within this region. A previous study ${ }^{30}$ used alanine scanning mutagenesis to identify four residues in XylS required for the recognition of the A boxes (Arg242, Asn246, Glu249 and Lys250) and five required for the interaction with boxes B (G295, Arg296, Asp299, Asn300 and Arg302). As can be observed in the protein alignment between BenR and XylS homologues, most of these positions are well conserved in the proteins analyzed, with an exception for this been Asn246, Lys250 and Asn300 (Fig. 1A). It is surprising to notice that, while the change of Asn to Ala at position 246 in XylS reduced by a half the capability of this protein to activate $\mathrm{Pm}$, an Ala is found well-conserved in most BenR protein analyzed. This indicates that BenR homologues might be less stringent in the interaction at the $\mathrm{A}$ box of the target promoter ${ }^{25}$. In the same direction of this hypothesis, analysis of $\mathrm{Pm}$ and $\mathrm{Pb}$ promoters from several Pseudomonas strains reveals that most features (A and B boxes, $-35 / 10$ region) are well conserved, except for the A box of $\mathrm{Pb}$ (the target of the BenR studied here) from Pseudomonas putida KT2440 (Fig. 1B). In this sense, to check the effect of the A box on the interaction between XylS and $P m$ and $P b$ promoters, we assayed the promoter activity using a lux reporter system. We used a wild type xylS gene expressed from a pSEVA vector ${ }^{31}$ and $P m, P b$ and $P b$-syn1 (a $P b$ variant with the recomposed $\mathrm{A}$ box of $O d$ region ${ }^{25}$ ). Using this system, we observed that while XylS could recognize $P m$ very efficiently, it was not able to induce $P b$ activity in response to the inducers tested (Fig. 2). However, when a version of $P b$ with the reconstituted $A$ box (Pb-syn1) was used, we could observe a strong induction of promoter activity in response to the inducers used. Taken together, these results reinforce the notion that while XylS has a critical requirement for complete $A$ and $B$ boxes at the $O d$ and Op regions, BenR is less stringent for promoter recognition ${ }^{25}$.

\section{A single amino acid position is critical for aromatic recognition in BenR and XyIS}

After tracing critical differences in the DNA recognition requirements between BenR and XylS, we decided to investigate aa differences that could explain the divergence in the ligand selectivity between these two TFs. As presented before, BenR has a very narrow inducer selectivity as this TF can only respond to benzoate as inducer under natural conditions. However, XylS can be activated by a diverse collection of aromatic inducers, such as benzoate and methylated or chlorinated benzoate analogues ${ }^{27}$. In order to gain insight into the molecular mechanisms responsible for these differences, we constructed a 3D protein structure for the $\mathrm{N}$-terminal region of BenR using homology modelling. The resulting model was subject to molecular docking using benzoate, 3methylbenzoate $(3 \mathrm{MBz}), 4-$ methylbenzoate $(4 \mathrm{MBz})$ and salicylate (Sal). Using this approach, we obtained a protein structural model (Fig. 3A) and identified a potential cavity on the protein surface that accommodates well a benzoate molecule (Fig. 3B). Additionally, the potential binding pocket identified did not support well the binding of the benzoate analogues, suggesting a mode of inducer selectivity based on size exclusion. By analyzing the model and predicted binding pocket, we could identify 9 aa located from positions 67 to 121 that 
bioRxiv preprint doi: https://doi.org/10.1101/400788; this version posted August 27, 2018. The copyright holder for this preprint (which was not certified by peer review) is the author/funder, who has granted bioRxiv a license to display the preprint in perpetuity. It is made available under aCC-BY-NC-ND 4.0 International license.

contributed to the surface of the cavity (Fig. 3C). With this information, we analyzed the conservation of these aa between BenR and XyIS, hypothesizing that a change in some of these aa could explain the difference in ligand specificity between these two regulators. For our surprise, 8 out 9 aa from the predicted binding pocket were conserved between the two proteins. The only difference was at position 111, which is a Valine in BenR and an Alanine in XylS. Since Alanine has a shorter side chain, we hypothesized that this could lead to a wider binding pocket in XyIS that could accommodate the methylated or chlorinated benzoate analogues. In order to investigate this possibility, we constructed point mutations in benR and $x y / S$ at aa positions 111 and 110 , as we notice that this last position, while not involved in the binding pocket, was also not conserved between the two regulators (Fig. 4A). In addition to the point mutations, we constructed a chimaera between the N-terminal part of XyIS and the C-terminal part of BenR and subjected this TF also to mutagenesis. All assays were performed using the cognate promoter for each TF (i.e., $P b$ for BenR and $P m$ for XylS) controlling a GFP reporter gene to allow investigation at the single cell level ${ }^{32,33}$ (Fig. 4A). As can be observed in Fig. 4B, wildtype BenR was specific to benzoate at all concentrations tested, while wildtype XylS displayed preferential response to $3 \mathrm{MBz}$, an intermediated response to benzoate and lower response to $2 \mathrm{MBz}$ and $4 \mathrm{MBz}$. When we mutated the position 110 of BenR from Pro to Ala or Gln (the aa found at this position in XylS), we could observe that the mutants presented the same expression profile of the wildtype but with reduced efficacy (Fig. 4C). However, when position 111 was changed from Val to Ala in BenR, the resulting protein variant did not display any response to the inducers tested. Contrary to the expected, changing Val at position 111 to Ala did not widen the inducer specificity of BenR. By the same token, the construction of BenR mutants with changes at both positions 110 and 111 resulted also in non-functional proteins (Fig. S1), potentially due to the role of Val111 on signal recognition. Taken together, these results indicate that Val111 is key for inducer recognition by BenR and strengthens the identification of the effector-binding pocket identified by homology modeling and molecular docking.

The construction of the chimeric protein harboring the N-terminal of XylS (the region responsible for ligand recognition) and the C-terminal of BenR (which recognizes DNA) resulted in the new protein X-BenR that displayed an induction profile similar to that of XyIS but with a reduced efficacy (Fig. 4D). This result conformed that the required elements for inducer selectivity are placed in the first 196 aa of the proteins. In order to check the role of position 111 in the inducer selectivity of XyIS, we constructed point mutants of XyIS and X-BenR changing the Alanine at this position for a Valine. Unexpectedly, the resulting mutant proteins displayed an enhanced response to the optimal inducer ( $3 \mathrm{MBz}$ ) as well as to the sub-optimal inducers benzoate, $2 \mathrm{MBz}, 4 \mathrm{Mbz}$ and salicylic acids (Fig. 4D). On the other hand, attempts to construct a chimeric protein harboring the N-terminal of BenR and the C-terminal of XyIS (named B-XyIS) resulted in non-functional products with no detectable response to benzoate or $3 \mathrm{MBz}$ (Fig. S2). Yet, single cell analysis of promoter induction by flow cytometry shows that while wildtype BenR and XylS-based expression systems presented clear unimodal patterns, the X-BenR chimaera and mutated version of XylS and X-BenR displayed a wider population distribution that could indicate stable sub-populations (Fig. S3 to Fig. S5). Taken together, these results evidenced a remarkably different role of position 111 between BenR and XyIS, which led to identification of two TFs variants with enhanced response to a wide range of benzoate derivatives.

\section{A new set of TFs responsive to different aromatic compounds and Aspirin ${ }^{T M}$}

Building on the data above regarding inducer recognition of BenR and XyIS, we developed novel TFs variants with reverse engineered ligand and promoter specificities. Fig. 5 represents the overall performances of the new TFs in response to a set of benzoate derivate (Fig. 5A). As shown in Fig. 5B, BenR and X-BenR produced the lowest promoter output and are exclusively responsive to benzoate (BenR) or $3 \mathrm{MBz}$ (X-BenR). As these proteins have a BenR C-terminal domain, they can recognize both $P m$ and $P b$. On the other hand, XylS has the intermediate level of promoter output and preference for $3 \mathrm{MBz}$, followed by benzoate and only minor response to $2 \mathrm{MBz}$ and $4 \mathrm{MBz}$. Yet, the mutated version of X-BenR (X-BenR-A111V) promoted an overall increased response to the suboptimal inducers of XylS and also response to Aspirin and ASA. Finally, the mutated version of XyIS (XylS-A111V) display a tremendous gain of response to all benzoate derivatives tested, including Aspirin and ASA, with promoter outputs similar to that of wildtype XylS induced with their optimal inducer 3MBz (Fig. 5B). When fold-change is calculated relative to non-induced conditions, it can be noticed that maximal induction of XylS-A111V system ( 76 times) outcompetes that of wildtype XyIS ( 69 times, Fig. 5 C). In this new system, the response to ASA reach 42 and 45 times, respectively. Yet, as this enhanced response could be the result of the construction of a TF with a promiscuous effector specificity, we tested the response of XyIS-A111V to toluene, 
bioRxiv preprint doi: https://doi.org/10.1101/400788; this version posted August 27, 2018. The copyright holder for this preprint (which was not certified by peer review) is the author/funder, who has granted bioRxiv a license to display the preprint in perpetuity. It is made available under aCC-BY-NC-ND 4.0 International license.

xylene, phenol and a number of non-aromatic inducers (L-arabinose, fructose, glucose, IPTG and arsenite). As can be observed in Fig. S6, the system did not respond to any of these compounds, supporting the notion that only benzoate derivate could induce this mutated regulator.

\section{Discussion}

The results presented here shed some light on the molecular mechanisms for single recognition of BenR and XyIS from $P$. putida. Of particular interest, XyIS has been extensively investigated both on the context of the natural regulation of the meta pathways in $P$. putida mt-2 ${ }^{34,35,36}$ as well as for its applicability as a universal expression system for gram-negative bacterium ${ }^{12,37,38}$. Previous attempts have investigated the critical aa for inducer recognition and promoter activation 12,30,39, but these studies have not provided a clear molecular proposition on how this protein interacts with its ligands or the promoter. On the other hand, fewer studies have investigated BenR at the molecular detail $24,25,26,40$. As for the founds presented here, we initially expect that changes in the aa of the identified binding pocket of BenR could adjust the ligand selectivity of the protein, as reported for the TtgV regulator that can discriminate between molecules with one or two aromatic rings ${ }^{41,42}$. Yet, contrary to the initial size exclusion model proposed, our experimental validation of the binding site prediction supports a role for position 111 in both BenR and XylS as a key element connecting the binding of the ligand to the changes in domain arrangement of the protein, similarly to the mechanism of activation of AraC of $E$. coli ${ }^{43}$. In this sense, the modelling of BenR with both $\mathrm{N}$ - and $\mathrm{C}$-terminal domains suggest that the residue 111 is close to the interface between the ligand binding and DNA binding domains (Fig. S7 and S8). In this scenario, Valine could make critical interactions in BenR that are disrupted when this aa is changed for Alanine. In the same way, changing Alanine in XylS (or in X-BenR) for Valine would allow the establishment of novel interactions that could enhance the performance of the protein, allowing the recognition of novel inducers such as salicylate or ASA. Previous work aiming the construction of XyIS-Pm expression with increased response to $3 \mathrm{MBz}$ have reported several mutations in both the $\mathrm{N}$ - and $\mathrm{C}$-terminal region of XyIS. Among these mutants, an A111V mutation have been reported, but this mutation was selected together with one or two additional positions ${ }^{12}$. Therefore, the role of position 111 in XyIS has never been investigated in isolation.

It is interesting to notice that the mutations affecting signal specific of BenR and XylS either completely abolish protein activity or generated regulators with enhanced response to a series of ligand. in other words, it was not possible to switch the specific of the ligand-binding domains from one compound to another. This notion resembles the stem protein model investigated for XyIR (another aromatic responsive regulator from $P$. putida mt2 ), where selection of mutant proteins responsive to new ligands resulted in variants promiscuous to several aromatic compounds ${ }^{44}$. It is also important to notice that the computational approach used here predict ligand binding pocket together with conservation analysis of phylogenetically related protein homologues represents a powerful tool to guide the rational design of TF variants. Similar approaches could be applied to other members of the AraC/XylS family of TFs, as well as regulators from different families, aiming the generation of novel expression systems for inducers of interest. While NahR, a LysR-type transcriptional regulator, is able to induce gene expression in response to salicylate ${ }^{10}$, the TFs engineered here represent a new set of tools for the expression of genes of interest in response to salicylate and ASA. Additionally, the expression system based on XylS-A111V display a $\sim 10$-fold change in response to $10 \mu \mathrm{M}$ of ASA, in the range of the observed sensitivity for the natural ASA-responsive regulator NahR (which reaches a fold-change of 20 in response to similar concentration of the compound ${ }^{10}$ ). These concentrations are in the range of the physiological concentrations of ASA in blood, as this molecules can reach levels as high as $\sim 30 \mu \mathrm{M}$ after 20 min administration of the drug 45 . Taken together, all results demonstrate the expression of the genetic toolbox for the engineering of synthetic circuits inducible to safe drugs.

\section{Material and methods}

\section{Bacterial strains and growth conditions}

The plasmids and bacterial strains used in this study are listed in Table 1. Cloning and assay procedures were performed in E. coli DH5a. All DNA manipulations, including cloning, PCR and transformations of $E$. coli were performed according Sambrook et al. ${ }^{46}$. Bacterial strains were routinely grown in LB media supplemented with 36 
bioRxiv preprint doi: https://doi.org/10.1101/400788; this version posted August 27, 2018. The copyright holder for this preprint (which was not certified by peer review) is the author/funder, who has granted bioRxiv a license to display the preprint in perpetuity. It is made available under aCC-BY-NC-ND 4.0 International license.

$\mu \mathrm{g} \mathrm{mL}^{-1}$ chloramphenicol or, when necessary, in $\mathrm{M} 9$ minimal media $\left(6.4 \mathrm{~g} \mathrm{~L}^{-1} \mathrm{Na}_{2} \mathrm{HPO}_{4} \cdot 7 \mathrm{H}_{2} \mathrm{O}, 1.5 \mathrm{~g} \mathrm{~L}^{-1} \mathrm{KH}_{2} \mathrm{PO}_{4}\right.$, $0.25 \mathrm{~g} \mathrm{~L}^{-1} \mathrm{NaCl}, 0.5 \mathrm{~g} \mathrm{~L}^{-1} \mathrm{NH}_{4} \mathrm{Cl}, 2 \mathrm{mM} \mathrm{MgSO}, 0.1 \mathrm{mM}^{2}$ casamino acids, $1 \%$ glycerol) supplemented with chloramphenicol at $36 \mu \mathrm{g} \mathrm{mL}-1$. Liquid cultures were shaken at $180 \mathrm{rpm}$ at $37^{\circ} \mathrm{C}$ during approximately $16 \mathrm{~h}$. The aromatic compounds used as inducers were all purchased from Sigma-Aldrich.

\section{Plasmids constructions}

The benR gene, $P b e n R$ and $P b$ promoters were amplified by PCR using specific primers (Table 2) and $P$. putida KT2440 genomic DNA as template. The PCR products were digested with specific restriction enzymes (see underlined sequences in Table 2) and cloned into the pMR1 vector ${ }^{47}$, yielding the pMR1-BenR-Pb (BenR) construction. BenR mutants: pMR1-BenR-P110A (BenR-P110A), pMR1-BenR-P110Q (BenR-P110Q), pMR1BenR-V111A (BenR-V111A), pMR1-BenR-A110A111 (BenR-A110A111) and pMR1-BenR-Q110A111 (BenRQ110A111) were generated by CPEC site-directed mutagenesis methodology ${ }^{48}$, using the pMR1-BenR-Pb construction as template and the primers listed in Table 2 (mutated base pairs are highlighted in bold and underlined). The xylS gene, $P$ s and $P m$ promoters were amplified by PCR using pSEVA438 vector as template ${ }^{31}$, yielding the pMR1-XyIS-Pm (XyIS) construction. XyIS mutant pMR1-XyIS-A111V (XyIS-A111V) was constructed by CPEC site-directed mutagenesis, using pMR1-XyIS-Pm construction as template and primers listed in Table 2 (mutated base pairs are highlighted in bold and underlined). Two chimeric transcription factors were constructed. The first construction was generated by directly linking the N-terminal domain of XyIS and the C-terminal domain of BenR using respectively $P$. putida mt-2 and KT2440 strains as templates. The second construction was generated by linking the N-terminal domain of BenR and the C-terminal domain of XyIS using the pMR1-BenR-Pb and the pMR1-XylS-Pm as templates. All fragments were amplified by PCR. In the first construction, the PbenR promoter was cloned upstream the chimaera and the $P b$ promoter was cloned upstream the GFPlva reporter gene yielding the pMR1-X-BenR (X-BenR). The chimaera mutant pMR1-X-BenR-A111V (X-BenR-A111V) was constructed using the CPEC and the pMR1-X-BenR as template. In the second construction, the Ps and Pm promoters were cloned upstream the chimaera and the GFPlva reporter gene, respectively, generating the pMR1-B-XyIS (B-XyIS). All PCR amplifications ware performed using Phusion High-Fidelity DNA polymerase (Thermo Fisher Scientific). All resulting constructions were sequenced using dideosyterminal methods in order to confirm the correct assembly prior to the fluorescence assays.

\section{GFP fluorescence assay and data processing}

In order to measure the activity of all constructions performed in this work, plasmids were transformed into $E$. coli DH5a. Freshly-plated single colonies were grown in M9 minimal media supplemented with suitable antibiotics. The cultures $(10 \mu \mathrm{L})$ were then assayed in a 96-well microplates with $170 \mu \mathrm{L}$ of $\mathrm{M} 9$ minimal media and $20 \mu \mathrm{L}$ of the different compounds tested. When required, benzoic acid $(\mathrm{Bz}), 3$-methylbenzoic acid $(3 \mathrm{MBz}), 2-$ methylbenzoic acid (2MBz), 4-methylbenzoic acid (4MBz), salicylic acid (0-1000 $\mu \mathrm{M})$; acetylsalicylic acid, Bayer® Aspirin $^{\text {TM }}(1000 \mu \mathrm{M})$ and isopropil $\beta$-D-1-tiogalactopiranosida (IPTG), sodium arsenite, toluene, xylene, phenol, Larabinose, fructose and glucose $(100 \mu \mathrm{M})$ were used. Cell growth and GFP fluorescence were quantified using a Victor X3 plate reader (Perkin Elmer). The responsiveness of regulators was calculated as arbitrary units using the ratio between fluorescence levels and optical density at $600 \mathrm{~nm}$ (reported as GFP/OD ${ }_{600}$ ) or luminescence by optical density at $600 \mathrm{~nm}$ after background correction. As a control, all assays were performed without the addition of compounds as the threshold background signal during calculations. Fluorescence and absorbance measurements were taken at 30 min intervals up to $8 \mathrm{~h}$. All the experiments were performed in technical and biological triplicates. Raw data were processed using ad hoc R script (https://www.r-project.org/).

\section{Flow Cytometry Analysis}

High throughput single cell analysis of the bacteria carrying the BenR, XyIS, XBenR, XylS mutant or XBenR mutant systems was run as follows. First, we selected single colonies of the transformed strain (E. coli DH5a) and grow overnight in $\mathrm{M} 9$ minimal medium (containing $6.4 \mathrm{~g} / \mathrm{L} \mathrm{Na} 2 \mathrm{HPO} 4 \cdot 7 \mathrm{H} 2 \mathrm{O}, 1.5 \mathrm{~g} / \mathrm{L} \mathrm{KH} 2 \mathrm{PO} 4,0.25 \mathrm{~g} / \mathrm{L} \mathrm{NaCl}$, and $0.5 \mathrm{~g} / \mathrm{L} \mathrm{NH} 4 \mathrm{Cl})$ supplemented with $2 \mathrm{mM} \mathrm{MgSO} 4,0.1 \mathrm{mM} \mathrm{CaCl} 2,0.1 \mathrm{mM}$ casamino acids, chloramphenicol $(36 \mu \mathrm{g} / \mathrm{mL})$ and $1 \%$ glycerol as the sole carbon source (supplemented M9), at $37^{\circ} \mathrm{C}$ and $180 \mathrm{rpm}$. Next, overnight grown cells were diluted to 1:10 in fresh supplemented $\mathrm{M9}$, and was grown for three hours, at $37^{\circ} \mathrm{C}$ and $180 \mathrm{rpm}$. 
bioRxiv preprint doi: https://doi.org/10.1101/400788; this version posted August 27, 2018. The copyright holder for this preprint (which was not certified by peer review) is the author/funder, who has granted bioRxiv a license to display the preprint in perpetuity. It is made available under aCC-BY-NC-ND 4.0 International license.

At this point, the cultures were induced with different concentrations $(0 \mu \mathrm{M}, 10 \mu \mathrm{M}, 100 \mu \mathrm{M}, 250 \mu \mathrm{M}, 500 \mu \mathrm{M}$ and $1000 \mu \mathrm{M}$ ) of the inducers. BenR system was induced with benzoate, XylS with benzoate and 3-metilbenzoate, XBenR with 3-metilbenzoate, XylS mutant and X-BenR mutant with benzoate, 3-metil-Benzoate, Salicylic Acid and Acetyl-Salicylic Acid. After three hours of induction, the cultres were stored on ice and immediately analyzed for GFP fluorescence using the Millipore Guava EasyCyte Mini Flow Cytometer (Millipore). The results were analyzed by $\mathrm{R}$ scripts, using the flowCore and flowViz packages, available on Bioconductor (https://bioconductor.org/).

\section{D-structure model construction and docking analysis}

The 3D models presented here were generated by SWISS-MODEL server (https://swissmodel.expasy.org/) using the best homologue for each protein. For the visualization of the models, PyMol (https://pymol.org/) and Chimaera (https://www.cgl.ucsf.edu/chimaera/) were used. In order to predict the potential binding site for the aromatic ligands, Swiss-Docking (https://www.swissdock.ch/) and Docking Server (https://www.dockingserver.com/web) were used. Additionally, Jalview (http://www.jalview.org/) was used for the visualization of protein and DNA alignments generated by T-coffee (http://tcoffee.crg.cat/apps/tcoffee/all.html).

\section{Acknowledgments}

The authors are thanks to lab members for insightful discussion on this work. RS-R and MEG were supported by Young Research Awards, grant \#2012/22921-8 and 2015/04309-1, São Paulo Research Foundation (FAPESP). LMOM, AS-M, LM-S and LFA were supported by FAPESP PhD Fellowships (grant \#2016/19179-9, 2016/06323-4, 2017/17924-1 and 2018/04810-0).

\section{References}

1. Browning DF, Busby SJ. Local and global regulation of transcription initiation in bacteria. Nat Rev Microbiol 14, $638-650$ (2016).

2. Galán-Vásquez E, Sánchez-Osorio I, Martínez-Antonio A. Transcription Factors Exhibit Differential Conservation in Bacteria with Reduced Genomes. PLoS One 11, e0146901 (2016).

3. Gama-Castro S, et al. RegulonDB version 9.0: high-level integration of gene regulation, coexpression, motif clustering and beyond. Nucleic Acids Res 44, D133-143 (2016).

4. Steinacher A, Bates DG, Akman OE, Soyer OS. Nonlinear Dynamics in Gene Regulation Promote Robustness and Evolvability of Gene Expression Levels. PLoS One 11, e0153295 (2016).

5. Baumstark R, et al. The propagation of perturbations in rewired bacterial gene networks. Nature communications 6 , 10105 (2015).

6. Mannan AA, Liu D, Zhang F, Oyarzun DA. Fundamental Design Principles for Transcription-Factor-Based Metabolite Biosensors. ACS synthetic biology 6, 1851-1859 (2017).

7. Lee JW, et al. Creating Single-Copy Genetic Circuits. Mol Cell 63, 329-336 (2016).

8. Nielsen AA, et al. Genetic circuit design automation. Science 352, aac7341 (2016).

9. Unkles SE, Valiante V, Mattern DJ, Brakhage AA. Synthetic biology tools for bioprospecting of natural products in eukaryotes. Chem Biol 21, 502-508 (2014).

10. Shin HJ. Development of highly-sensitive microbial biosensors by mutation of the nahR regulatory gene. $J$ Biotechnol 150, 246-250 (2010). 
bioRxiv preprint doi: https://doi.org/10.1101/400788; this version posted August 27, 2018. The copyright holder for this preprint (which was not certified by peer review) is the author/funder, who has granted bioRxiv a license to display the preprint in perpetuity. It is made available under aCC-BY-NC-ND 4.0 International license.

11. Garmendia J, de las Heras A, Galvao TC, de Lorenzo V. Tracing explosives in soil with transcriptional regulators of Pseudomonas putida evolved for responding to nitrotoluenes. Microb Biotechnol 1, 236-246 (2008).

12. Vee Aune TE, Bakke I, Drablos F, Lale R, Brautaset T, Valla S. Directed evolution of the transcription factor XylS for development of improved expression systems. Microb Biotechnol 3, 38-47 (2010).

13. Bates DM, et al. Substitution of leucine 28 with histidine in the Escherichia coli transcription factor FNR results in increased stability of the [4Fe-4S](2+) cluster to oxygen. J Biol Chem 275, 6234-6240 (2000).

14. Shis DL, Hussain F, Meinhardt S, Swint-Kruse L, Bennett MR. Modular, multi-input transcriptional logic gating with orthogonal Lacl/GalR family chimaeras. ACS synthetic biology 3, 645-651 (2014).

15. Younger AK, Dalvie NC, Rottinghaus AG, Leonard JN. Engineering Modular Biosensors to Confer MetaboliteResponsive Regulation of Transcription. ACS synthetic biology 6, 311-325 (2017).

16. Stanton BC, Nielsen AA, Tamsir A, Clancy K, Peterson T, Voigt CA. Genomic mining of prokaryotic repressors for orthogonal logic gates. Nat Chem Biol 10, 99-105 (2014).

17. Libis V, Delepine B, Faulon JL. Sensing new chemicals with bacterial transcription factors. Curr Opin Microbio/ 33, 105-112 (2016).

18. Bikard D, Marraffini LA. Control of gene expression by CRISPR-Cas systems. F1000Prime Rep 5, 47 (2013).

19. Bikard D, Jiang W, Samai P, Hochschild A, Zhang F, Marraffini LA. Programmable repression and activation of bacterial gene expression using an engineered CRISPR-Cas system. Nucleic Acids Res 41, 7429-7437 (2013).

20. Qi LS, et al. Repurposing CRISPR as an RNA-guided platform for sequence-specific control of gene expression. Cell 152, 1173-1183 (2013).

21. Libis V, Delepine B, Faulon JL. Expanding Biosensing Abilities through Computer-Aided Design of Metabolic Pathways. ACS synthetic biology 5, 1076-1085 (2016).

22. de los Santos EL, Meyerowitz JT, Mayo SL, Murray RM. Engineering Transcriptional Regulator Effector Specificity Using Computational Design and In Vitro Rapid Prototyping: Developing a Vanillin Sensor. ACS synthetic biology 5, 287-295 (2016).

23. Royo JL, et al. In vivo gene regulation in Salmonella spp. by a salicylate-dependent control circuit. Nat Methods 4, 937-942 (2007).

24. Perez-Pantoja D, Kim J, Silva-Rocha R, de Lorenzo V. The differential response of the Pben promoter of Pseudomonas putida mt-2 to BenR and XyIS prevents metabolic conflicts in m-xylene biodegradation. Environ Microbiol, (2014).

25. Silva-Rocha R, de Lorenzo V. Broadening the signal specificity of prokaryotic promoters by modifying cisregulatory elements associated with a single transcription factor. Mol Biosyst 8, 1950-1957 (2012).

26. Cowles CE, Nichols NN, Harwood CS. BenR, a XyIS homologue, regulates three different pathways of aromatic acid degradation in Pseudomonas putida. J Bacteriol 182, 6339-6346 (2000).

27. Xue $\mathrm{H}$, et al. Design, construction, and characterization of a set of biosensors for aromatic compounds. ACS synthetic biology 3, 1011-1014 (2014).

28. Tobes R, Ramos JL. AraC-XylS database: a family of positive transcriptional regulators in bacteria. Nucleic Acids Res 30, 318-321 (2002).

29. Kessler B, de Lorenzo V, Timmis KN. Identification of a cis-acting sequence within the Pm promoter of the TOL plasmid which confers XylS-mediated responsiveness to substituted benzoates. J Mol Biol 230, 699-703 (1993).

30. Dominguez-Cuevas $\mathrm{P}$, Marin P, Marques S, Ramos JL. XylS-Pm promoter interactions through two helix-turn-helix motifs: identifying XyIS residues important for DNA binding and activation. J Mol Biol 375, 59-69 (2008). 
bioRxiv preprint doi: https://doi.org/10.1101/400788; this version posted August 27, 2018. The copyright holder for this preprint (which was not certified by peer review) is the author/funder, who has granted bioRxiv a license to display the preprint in perpetuity. It is made available under aCC-BY-NC-ND 4.0 International license.

31. Silva-Rocha R, et al. The Standard European Vector Architecture (SEVA): a coherent platform for the analysis and deployment of complex prokaryotic phenotypes. Nucleic Acids Res 41, D666-675 (2013).

32. Silva-Rocha R, de Lorenzo V. Stochasticity of TOL plasmid catabolic promoters sets a bimodal expression regime in Pseudomonas putida mt-2 exposed to m-xylene. Mol Microbiol, (2012).

33. Silva-Rocha R, de Lorenzo V. A GFP-lacZ bicistronic reporter system for promoter analysis in environmental gramnegative bacteria. PLoS One 7, e34675 (2012).

34. Moreno R, Fonseca P, Rojo F. The Crc global regulator inhibits the Pseudomonas putida pWW0 toluene/xylene assimilation pathway by repressing the translation of regulatory and structural genes. J Biol Chem 285, 24412-24419 (2010).

35. Gonzalez-Perez MM, Ramos JL, Marques S. Cellular XylS levels are a function of transcription of xylS from two independent promoters and the differential efficiency of translation of the two mRNAs. J Bacteriol 186, 1898-1901 (2004).

36. Marques S, Manzanera M, Gonzalez-Perez MM, Gallegos MT, Ramos JL. The XyIS-dependent Pm promoter is transcribed in vivo by RNA polymerase with sigma 32 or sigma 38 depending on the growth phase. Mol Microbiol 31, 11051113 (1999).

37. Blatny JM, Brautaset T, Winther-Larsen HC, Karunakaran P, Valla S. Improved broad-host-range RK2 vectors useful for high and low regulated gene expression levels in gram-negative bacteria. Plasmid 38, 35-51 (1997).

38. Blatny JM, Brautaset T, Winther-larsen HC. Construction and Use of a Versatile Set of Broad-Host-Range Cloning and Expression Vectors Based on the RK2 Replicon. 63, 370-379 (1997).

39. Dominguez-Cuevas P, Marin P, Busby S, Ramos JL, Marques S. Roles of effectors in XylS-dependent transcription activation: intramolecular domain derepression and DNA binding. J Bacteriol 190, 3118-3128 (2008).

40. Moreno R, Rojo F. The target for the Pseudomonas putida Crc global regulator in the benzoate degradation pathway is the BenR transcriptional regulator. J Bacteriol 190, 1539-1545 (2008).

41. Guazzaroni ME, Gallegos MT, Ramos JL, Krell T. Different modes of binding of mono- and biaromatic effectors to the transcriptional regulator TTGV: role in differential derepression from its cognate operator. J Biol Chem 282, 16308-16316 (2007).

42. Guazzaroni ME, et al. The multidrug efflux regulator TtgV recognizes a wide range of structurally different effectors in solution and complexed with target DNA: evidence from isothermal titration calorimetry. J Biol Chem 280, 20887-20893 (2005).

43. Schleif R. AraC protein, regulation of the l-arabinose operon in Escherichia coli, and the light switch mechanism of AraC action. FEMS Microbiol Rev 34, 779-796 (2010).

44. Galvao TC, Mencia M, de Lorenzo V. Emergence of novel functions in transcriptional regulators by regression to stem protein types. Mol Microbiol 65, 907-919 (2007).

45. Cotty VF, et al. Augmentation of human blood acetylsalicylate concentrations by the simultaneous administration of acetaminophen with aspirin. Toxicol Appl Pharmacol 41, 7-13 (1977).

46. Sambrook J, Fritsch EF, Maniatis T. Molecular cloning: A laboratory manual. Cold Spring Harbor (1989).

47. Guazzaroni ME, Silva-Rocha R. Expanding the logic of bacterial promoters using engineered overlapping operators for global regulators. ACS synthetic biology 3, 666-675 (2014).

48. Quan J, Tian J. Circular polymerase extension cloning for high-throughput cloning of complex and combinatorial DNA libraries. Nat Protoc 6, 242-251 (2011).

49. Bagdasarian M, et al. Specific-purpose plasmid cloning vectors. II. Broad host range, high copy number, RSF1010derived vectors, and a host-vector system for gene cloning in Pseudomonas. Gene 16, 237-247 (1981). 
bioRxiv preprint doi: https://doi.org/10.1101/400788; this version posted August 27, 2018. The copyright holder for this preprint (which was not certified by peer review) is the author/funder, who has granted bioRxiv a license to display the preprint in perpetuity. It is made available under aCC-BY-NC-ND 4.0 International license.

Tables

Table 1. Strains and plasmids used in this work.

\begin{tabular}{|c|c|c|}
\hline $\begin{array}{l}\text { Strains and } \\
\text { plasmids }\end{array}$ & Description & Reference \\
\hline \multicolumn{3}{|l|}{ Strains } \\
\hline P. putida KT2440 & P. putida mt-2 derivative & 49 \\
\hline E. coli DH5a & $\begin{array}{l}\text { F- } \varphi 80 \Delta \text { lacZ } \Delta M 15 \Delta(\text { lacZYAA-argF) U169 recA1 endA1 hsdR17 R-M+ } \\
\text { supE4 thi gyrA relA }\end{array}$ & 46 \\
\hline \multicolumn{3}{|l|}{ Plasmids } \\
\hline pSEVA438 & $\begin{array}{l}\text { Sm/SpR } \text {, ori pBBR1; Expression vector harboring the xylS-Pm expression } \\
\text { system }\end{array}$ & 31 \\
\hline pSEVA226 & $\mathrm{Km}^{\mathrm{R}}$, ori RK2; reporter vector harboring the luxCDABE operon & 31 \\
\hline pSEVA226- $P b$ & $\begin{array}{l}\text { KmR, ori RK2; pSEVA226 with the } P b \text { promoter cloned as a EcoRI/BamHI } \\
\text { fragment }\end{array}$ & 25 \\
\hline pSEVA226-Pm & $\begin{array}{l}\text { KmR, ori RK2; pSEVA226 with the Pm promoter cloned as a EcoRI/BamHI } \\
\text { fragment }\end{array}$ & 25 \\
\hline pSEVA226-Pbsyn1 & $\begin{array}{l}\text { KmR ori RK2; pSEVA226 with the Pbsyn1 promoter cloned as a EcoRI/BamHI } \\
\text { fragment }\end{array}$ & 25 \\
\hline pMR1 & $\mathrm{Cm}^{\mathrm{R}}$, ori p15a; dual mCherry/GFPlva promoter probe vector & 47 \\
\hline pMR1-BenR-Pb & $\begin{array}{l}\mathrm{Cm}^{\mathrm{R}} \text {, ori } \mathrm{p} 15 \mathrm{a} ; \mathrm{pMR} 1 \text { variant with ben } \mathrm{R}-\mathrm{Pb} \text { expression system closed as a } \\
B g(I I / E \mathrm{E} \text { RI fragment }\end{array}$ & This study \\
\hline pMR1-BenR-V111A & $\mathrm{Cm}^{\mathrm{R}}$, ori p15a; pMR1-BenR-Pb with benR gene mutated at position V111A & This study \\
\hline pMR1-BenR-P110A & $\mathrm{Cm}^{\mathrm{R}}$, ori $\mathrm{p} 15 \mathrm{a}$; pMR1-BenR-Pb with benR gene mutated at position $\mathrm{P} 110 \mathrm{~A}$ & This study \\
\hline pMR1-BenR-P110Q & $\mathrm{Cm}^{\mathrm{R}}$, ori p15a; pMR1-BenR-Pb with benR gene mutated at position P110Q & This study \\
\hline $\begin{array}{l}\text { pMR1-BenR- } \\
\text { A110A111 }\end{array}$ & $\begin{array}{l}\mathrm{Cm}^{R} \text {, ori p15a; pMR1-BenR-Pb with benR gene mutated at positions P110A } \\
\text { and V111A }\end{array}$ & This study \\
\hline $\begin{array}{l}\text { pMR1-BenR- } \\
\text { Q110A111 }\end{array}$ & $\begin{array}{l}\mathrm{Cm}^{\mathrm{R}} \text {, ori p15a; pMR1-BenR-Pb with benR gene mutated at positions P110Q } \\
\text { and V111A }\end{array}$ & This study \\
\hline pMR1-X-BenR & $\begin{array}{l}\mathrm{Cm}^{R} \text {, ori p15a; pMR1-BenR-Pb with benR with the N-terminal region replaced } \\
\text { by that of } x y / S\end{array}$ & This study \\
\hline $\begin{array}{l}\text { pMR1- X-BenR- } \\
\text { A111V }\end{array}$ & $\begin{array}{l}\mathrm{Cm}^{\mathrm{R}} \text {, ori p15a; pMR1-X-BenR with chimeric X-benR gene mutated at position } \\
\text { A111V }\end{array}$ & This study \\
\hline pMR1-XyIS-Pm & $\begin{array}{l}\mathrm{Cm}^{R} \text {, ori p15a; pMR1 variant with xylS-Pm expression system closed as a } \\
\text { Bglll/EcoRI fragment }\end{array}$ & This study \\
\hline $\begin{array}{l}\text { pMR1-XylS-Pm- } \\
\text { A111V }\end{array}$ & $\mathrm{Cm}^{\mathrm{R}}$, ori p15a; pMR1-XyIS-Pm with xylS gene mutated at position A111V & This study \\
\hline pMR1-B-XylS & $\begin{array}{l}\mathrm{Cm}^{\mathrm{R}} \text {, ori p15a; pMR1-XyIS-Pm with xylS with the N-terminal region replaced by } \\
\text { that of benR }\end{array}$ & This study \\
\hline
\end{tabular}

Table 2: Primers used for each clone constructed in this work.

\begin{tabular}{|c|c|c|}
\hline Primer & Sequence & Template \\
\hline 5 benR EcoRI & CGCGGAATTCAAGTACCGGAAGATACTGTTCG & P. putida KT2440 \\
\hline 3 benR Bglll & CGCGAGATCTGCAAAGCGCTCGCAACTGG & P. putida KT2440 \\
\hline $5 \mathrm{~Pb}$ EcoRI & CGCGGAATTCCTTTGAGAAGGAACGTCTCC & P. putida KT2440 \\
\hline $3 \mathrm{~Pb}$ BamHI & CGCGGGATCCCCCTTGTTATTGTTTAGACCTGG & P. putida KT2440 \\
\hline 5 BenR V111A & GATCAACCCGGACGACCCGGㄷGGACCTGACTTACTCGGAAG & pMR1-BenR-Pb \\
\hline
\end{tabular}




\begin{tabular}{|c|c|c|}
\hline 3 BenR V111A & CTTCCGAGTAAGTCAGGTCAGCCGGGTCGTCCGGGTTGATC & pMR1-BenR-Pb \\
\hline 5 BenR P110A & GATCAACCCGGACGACGCGGTTGACCTGACTTACTCGGAAG & pMR1-BenR-Pb \\
\hline 3 BenR P110A & CTTCCGAGTAAGTCAGGTCAACCGㄷGTCGTCCGGGTTGATC & pMR1-BenR-Pb \\
\hline 5 BenR P110Q & GATCAACCCGGACGACCAGGTTGACCTGACTTACTCGGAAG & pMR1-BenR-Pb \\
\hline 3 BenR P110Q & CTTCCGAGTAAGTCAGGTCAACCTGGTCGTCCGGGTTGATC & pMR1-BenR-Pb \\
\hline 5 BenR A110A111 & GATCAACCCGGACGACGCGGㄷTGACCTGACTTACTCGGAAG & pMR1-BenR-Pb \\
\hline 3 BenR A110A111 & CTTCCGAGTAAGTCAGGTCAGCCGEGTCGTCCGGGTTGATC & pMR1-BenR-Pb \\
\hline 5 BenR Q110A111 & GATCAACCCGGACGACCAGGㅡTGACCTGACTTACTCGGAAG & pMR1-BenR-Pb \\
\hline 3 BenR Q110A111 & CTTCCGAGTAAGTCAGGTCAGCCIGGTCGTCCGGGTTGATC & pMR1-BenR-Pb \\
\hline 5 benR EcoRI & CGCGGAATTCAAGTACCGGAAGATACTGTTCG & P. putida KT2440 \\
\hline 3 PbenR-XylS-Chim & CGTTCAATAAGCAAAAATTCCATAGGCAAGGCACTCGGTATC & P. putida KT2440 \\
\hline 5 PbenR-XylS-Chim & GATACCGAGTGCCTTGCCTATGGATTTTTGCTTATTGAACG & P. putida MT-2 \\
\hline 5 XylS-BenR-Chim & GGCGGATATTGGTGCTCATTTCGAGCAGCT & P. putida MT-2 \\
\hline 3 XylS-BenR-Chim & AGCTGCTCGAAATGAGCACCAATATCCGCC & P. putida KT2440 \\
\hline 3 benR Bglll & CGCGAGATCTGCAAAGCGCTCGCAACTGG & P. putida KT2440 \\
\hline $5 \mathrm{XyIS}$ A111V & TTGCTGCTCAATCCGGATGACCAAGICGACCTGACCTATTCAGAAGATTGC & pMR1-X-BenR \\
\hline 3 XylS A111V & GCAATCTTCTGAATAGGTCAGGTCGACTTGGTCATCCGGATTGAGCAGCAA & pMR1-X-BenR \\
\hline 5 XylS EcoRI & CGCGGAATTCTCAAGCCACTTCCTTTTTGCATTG & pSEVA438 \\
\hline 3 Pm BamHI & CGCGGGATCCATTATTGTTTCTGTTGCATAAAGCC & pSEVA438 \\
\hline 5 XyIS A111V & TTGCTGCTCAATCCGGATGACCAAGICGACCTGACCTATTCAGAAGATTGC & pMR1-Xyls-Pm \\
\hline 3 XylS A111V & GCAATCTTCTGAATAGGTCAGGTCGACTTGGTCATCCGGATTGAGCAGCAA & pMR1-Xyls-Pm \\
\hline Quim_Ps_Pm_F & CGCGGAATTCAGTTCACGGTTCTCTTATTTT & pMR1-Xyls-Pm \\
\hline Quim_Ps_Pm_R & CGCGGGATCCATTATTGTTTCTGTTGCATAAAGCC & pMR1-Xyls-Pm \\
\hline Quim_Bglll_F1 & CGCGAGATCTTCAAGCCACTTCCTTTTTGCATTGA & pMR1-Xyls-Pm \\
\hline Quim_R1 & AAGCTGCTGACTCTGATGCTGGGCAGCAATGTCAGC & pMR1-Xyls-Pm \\
\hline Quim_F2 & GCTGACATTGCTGCCCAGCATCAGAGTCAGCAGCTT & pMR1-BenR-Pb \\
\hline Quim_EcoRI_R2 & CGCGGAATTCATGGAAAGCCGCCTGCTGAGCGAGC & pMR1-BenR-Pb \\
\hline
\end{tabular}

*Enzyme restriction sites are underlined

** Mutated base pairs are highlighted in bold and underlined

\section{Figure Legends}

Figure 1. Analysis of BenR homologues and target promoters in Pseudomonas. A) Analysis of protein conservation between XylS from Pseudomonas putida mt-2, and BenR homologues from strains of $P$. putida (Ppu_3159, Pput_2555, PputGB1_2689, PputW619_2886, PPS_2765), P. entomophila (PSEEN3143), P. fluorescens (Pfl01_2968, PFL_3858) and P. aeruginosa (PA14_32080, PLES_27771, PA2518). Only the region relative to the HTH domain is shown. Critical aa for DNA recognition (labeled as A-binding and B-binding) are marked with inverted triangles, with conserved regions colored in yellow. On the middle, schematic representation of BenR interaction with the RNAP and the target promoter, shown the two binding sites (Od and $O p$ ) and the $-35 /-10$ boxes at $P b$ and $P m$. B) Promoter alignment for $P m$ from $P$. putida mt-2 and for $P b$ from several Pseudomonas strains. The two conserved boxes (A and B) from $O d$ and $O p$ binding sites are highlighted. 
bioRxiv preprint doi: https://doi.org/10.1101/400788; this version posted August 27, 2018. The copyright holder for this preprint (which was not certified by peer review) is the author/funder, who has granted bioRxiv a license to display the preprint in perpetuity. It is made available under aCC-BY-NC-ND 4.0 International license.

Figure 2. Recognition of $\mathrm{Pm}$ and $\mathrm{Pb}$ by XylS. For the analysis, E. coli DH5a strain was transformed with pSEVA438 (harboring a functional XyIS expressed with its native promoter ${ }^{31}$ ) and pSEVA226 (a reporter vector with the luxCDABE operon ${ }^{31}$ ) harboring $P m, P b$ or $P b$-syn1, a variant of $P b$ endowed with the $A$ box of $O d$ from $P m^{25}$. all strains were grown on minimal media to mid-exponential phase and then expose for 3 hours to $100 \mu \mathrm{M}$ of benzoate (Bz), 3-methylbenzoate (3MBz), 3-chlorobenzoate (3CBz) or 4-methylbenzoate (4MBz). The results represent fold change of promoter activity relative to the non-induced condition.

Figure 3. Mapping ligand binding site in BenR by protein structure prediction and molecular docking. A) Homology model of wild type (left) and V111A mutant (right) of BenR, with zoom at the larger cavity of both models shown on the bottom. B) Docking of benzoate (Bz), 3-methylbenzoate (3MBz), 4-methylbenzoate (4MBz) and salicylate (Sal) at the wild type BenR protein, with the molecules shown in red. C) mapping of the aa forming the potential binding site for benzoate at BenR (top) and the model for the interaction with the molecule in the bottom.

Figure 4. Experimental identification of critical aa for inducer recognition in BenR and XyIS. A) Schematic representation of BenR and the chimeric protein X-BenR (a fusion between the N-terminal domain of XylS with the C-terminal domain of BenR), showing the non-conversed position 110 and 111 tested here. All protein variants were tested with a GFPlva reporter under the control of the cognate promoter (i.e., $P b$ for BenR and XBenR and $P m$ for XylS). B) Analysis of promoter activity of BenR-Pb and XylS-Pm in response to different concentrations of benzoate (Bz), 3-methylbenzoate (3MBz), 2-methylbenzoate (2MBz), 4-methylbenzoate (4MBz) and acetyl salicylate acid (Ac. Sal). Solid line indicates the average from three independent experiments while dashed lines represents the lower and higher limits of the standard deviation. C) Analysis of promoter activity for BenR mutants at position 110 (BenR-P110A and BenR-P110Q) and 111 (BenR-V111A). D) Analysis of promoter acitivty for chimeric X-BenR protein and its variant with a mutation in postion 111 (X-BenR-A111V), as well as for the mutated version of XylS (XyIS-A111V).

Figure 5. Analysis of transcriptional response to aromatic compounds and Aspirin. A) Schematic representation of the chemical structure of the different inducers tested. B) Promoter activity of the different proteins reported here after 3 hours of exposition of the different inducers. Aspirin refers to the commercial formulation obtained from a conversional drug store (with concentration adjusted to $100 \mu \mathrm{M}$ ), while acetylsalicylic acid refers to the pure compound obtained from Sigma-Aldrich. C) Fold-change calculated for each expression systemin response to the different inducers used. Error bars represent the standard deviation from thee independent experiments. 


\section{A}

xyls/1-321

Ppu_3159/1-318 Pput_2555/1-318 PputGB1_2689/1-318 PputW619_2886/1-318 PPS_2766/1-318 PSEEN $3012 / 1-316$ Pf101_2320/18-335 PLES 27761/1-318 PA14_32060/1-318 PA2519/1-318 PFL_3859/1-318

IS LER LA ELAMM SPRSLYNLFEKHAGTTPKNY IRNRKLES IRACLNDPSANVRS IT E IA LDYGFLH LGRFAEYRSAFGELPSDTL

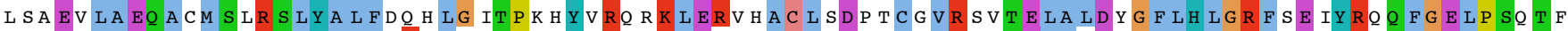
LTAEA LA EQACM SLRSLYA L F RH LQTTPKQYVRQRKLEQVRACLGDASCSVRSVTELAMDYGFLH LGR FEVYRQ FGELPSETL

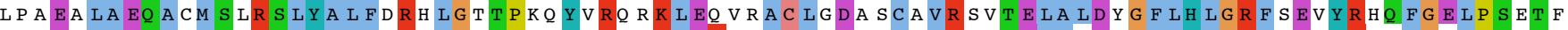

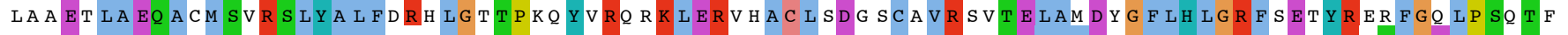

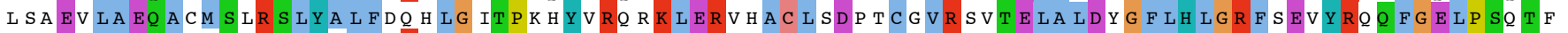

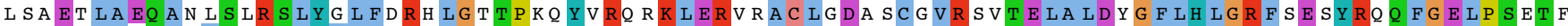

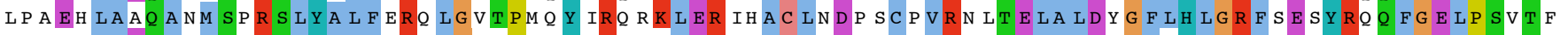
IEVA A L E E AHM STR S LYA L FER LGESPRQY IRR LR LER IRAC LEDPGCRVRN LT ELA LDFG FAH LGR FA EQRRQFGELPSETL

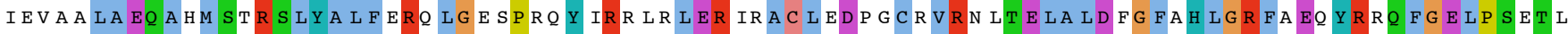

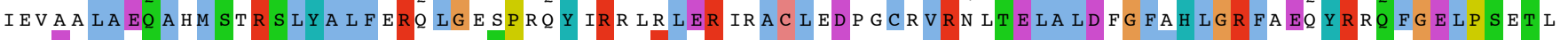

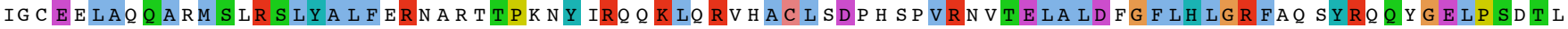

Conservatio

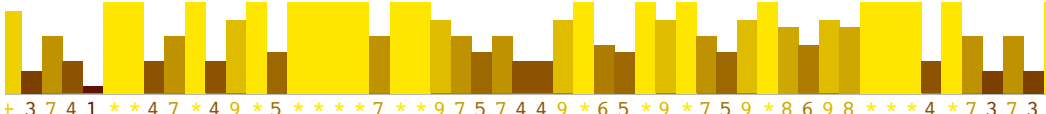

i
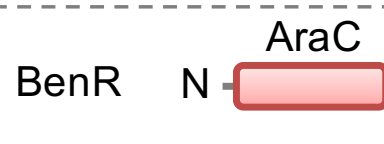

AraC

$\mathrm{HTH}$
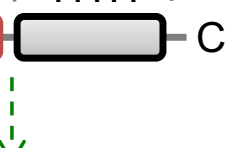

RNAP

B

$\mathrm{Pb}$

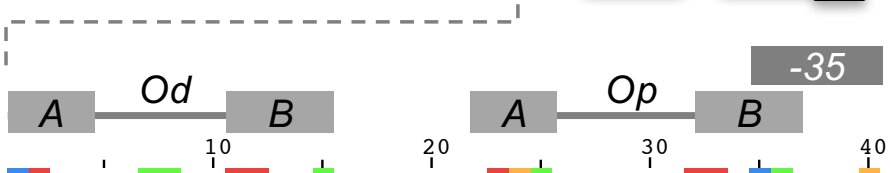

Pm/1-70

PbenA/1-70

Pput_2554/1-70

PputGB1 2688/1-70

PPS_2765/1-70

PputW619 2710/1-70

PSEEN $3143 / 1-70$

Pfl01_2968/1-70

PFL_3858/1-70

PA14_32080/1-70

PLES_27771/1-70

PA2518/1-70

T GCA a g a a g CGATA C a g g a

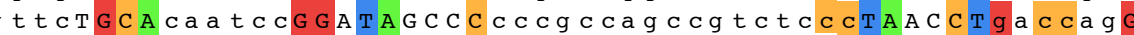

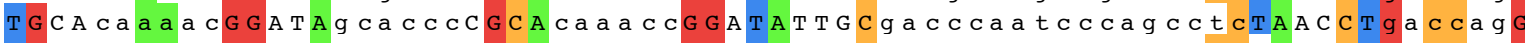

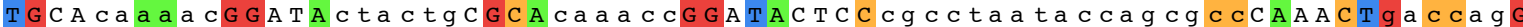

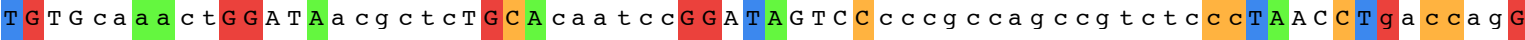

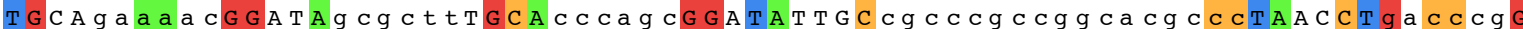

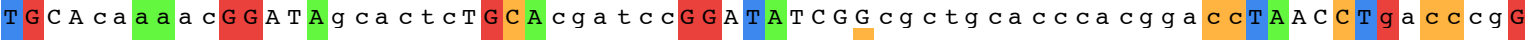

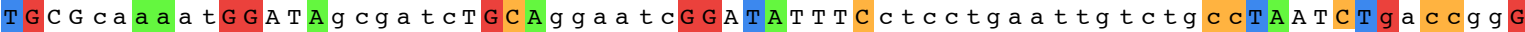

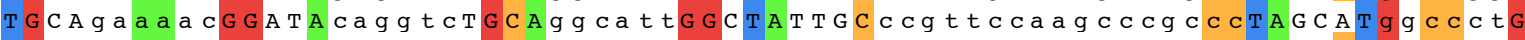

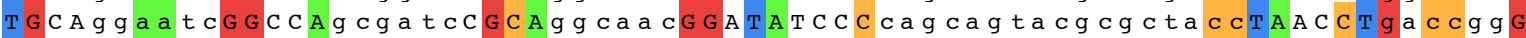

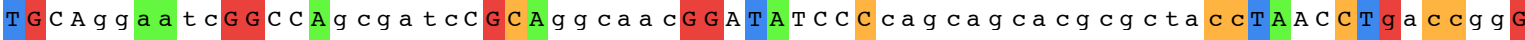

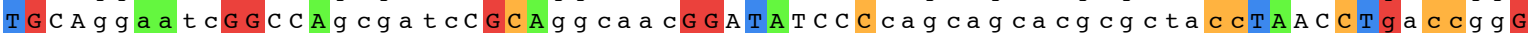


Xyls $\mathrm{N}=\mathrm{AraC}$

Promoter IUxCBABE

Pm

$\mathrm{Pb}$

Pb-syn 1
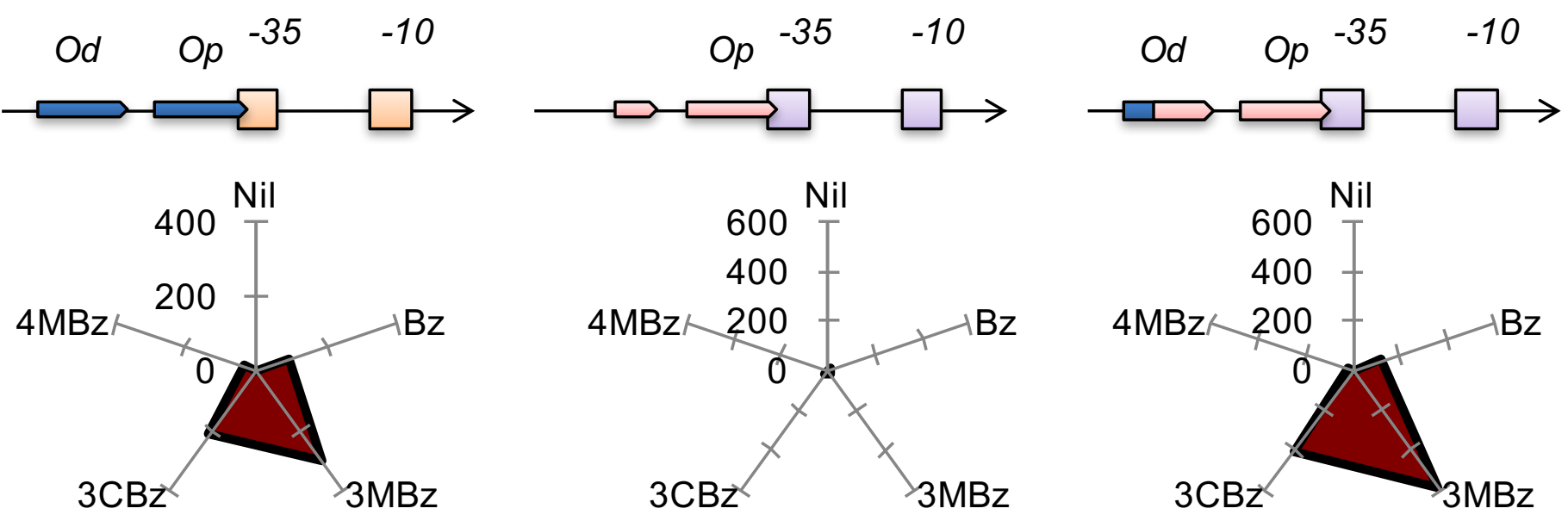

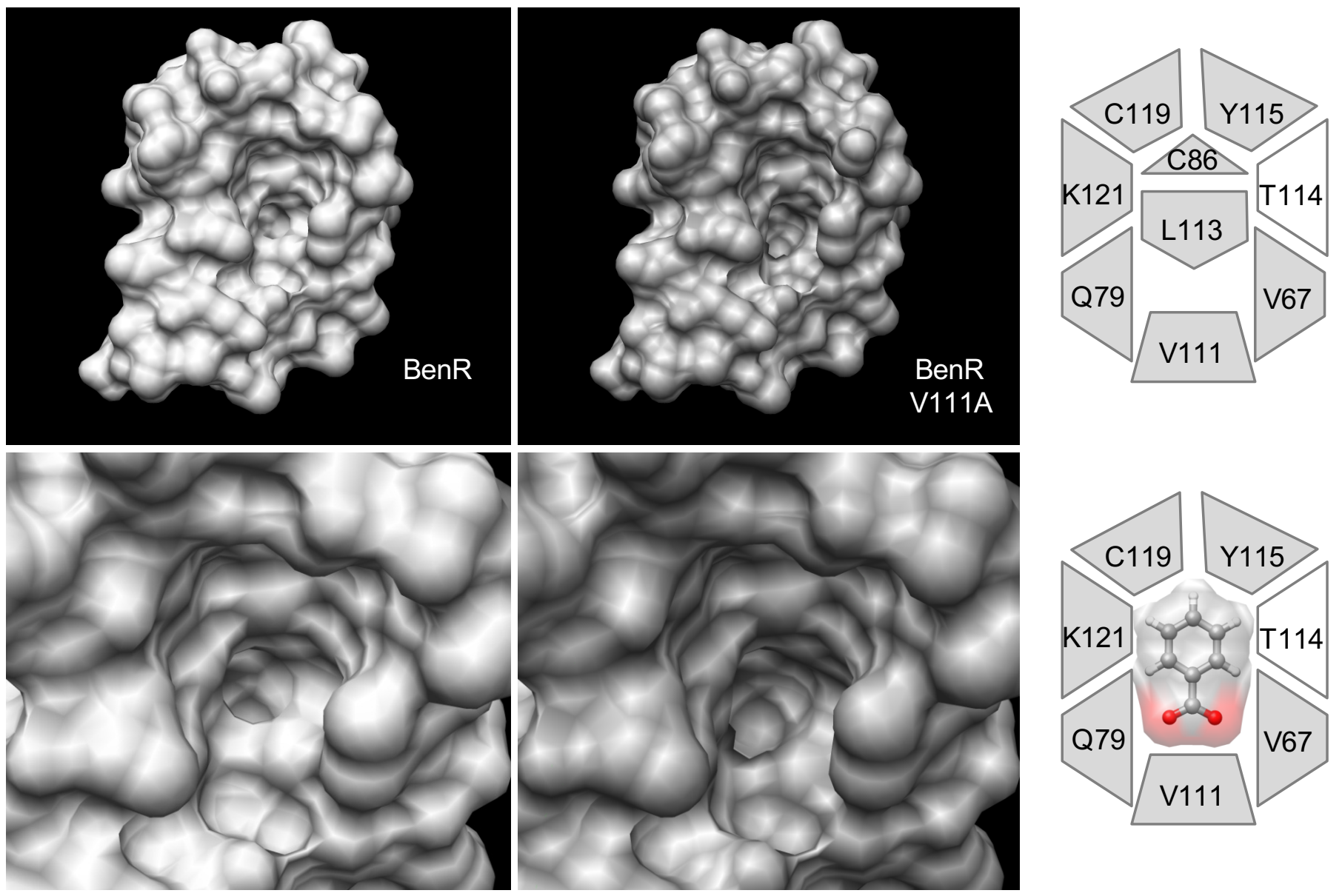

B

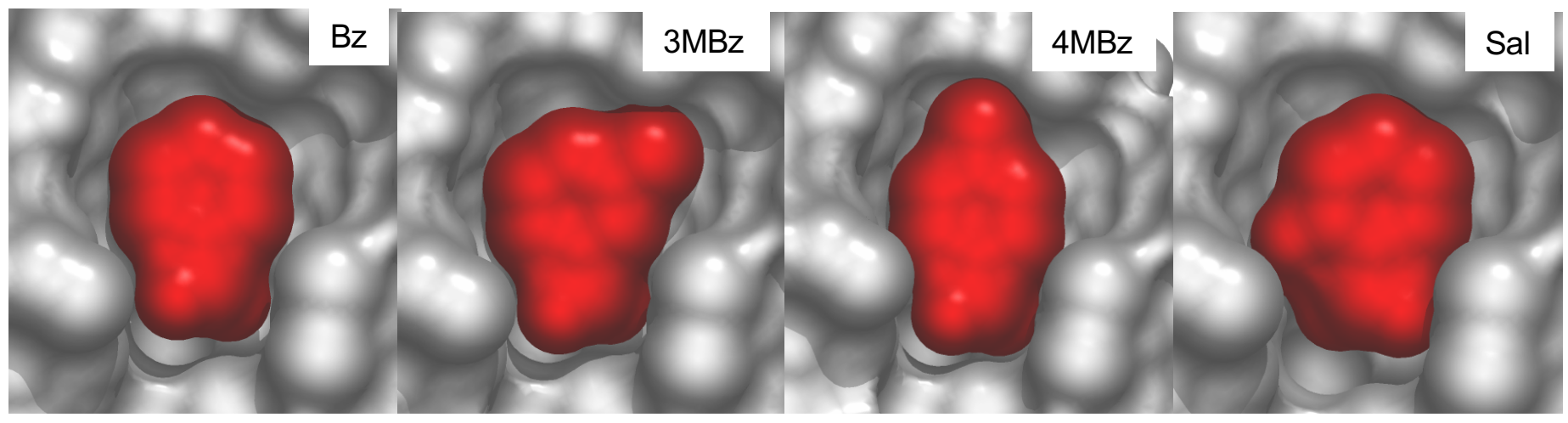


AraC $\mathrm{HTH}$ B BenR $\mathrm{N} \longrightarrow \mathrm{C}$ BenR 106 -NPDDPVDLTY-115 XYIS $106-N P D D Q A D L T Y-115$

AraC $\mathrm{HTH}$

$\mathrm{X}$-BenR $\mathrm{N}=\mathrm{C}$

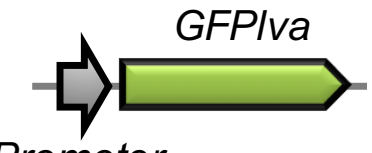

Promoter

C
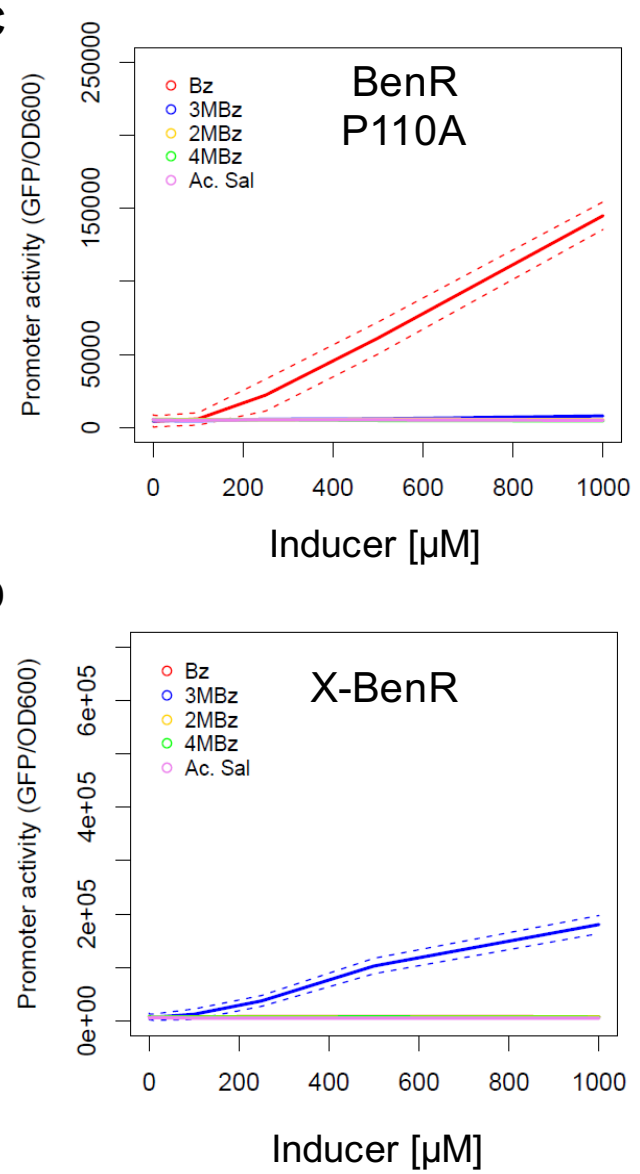
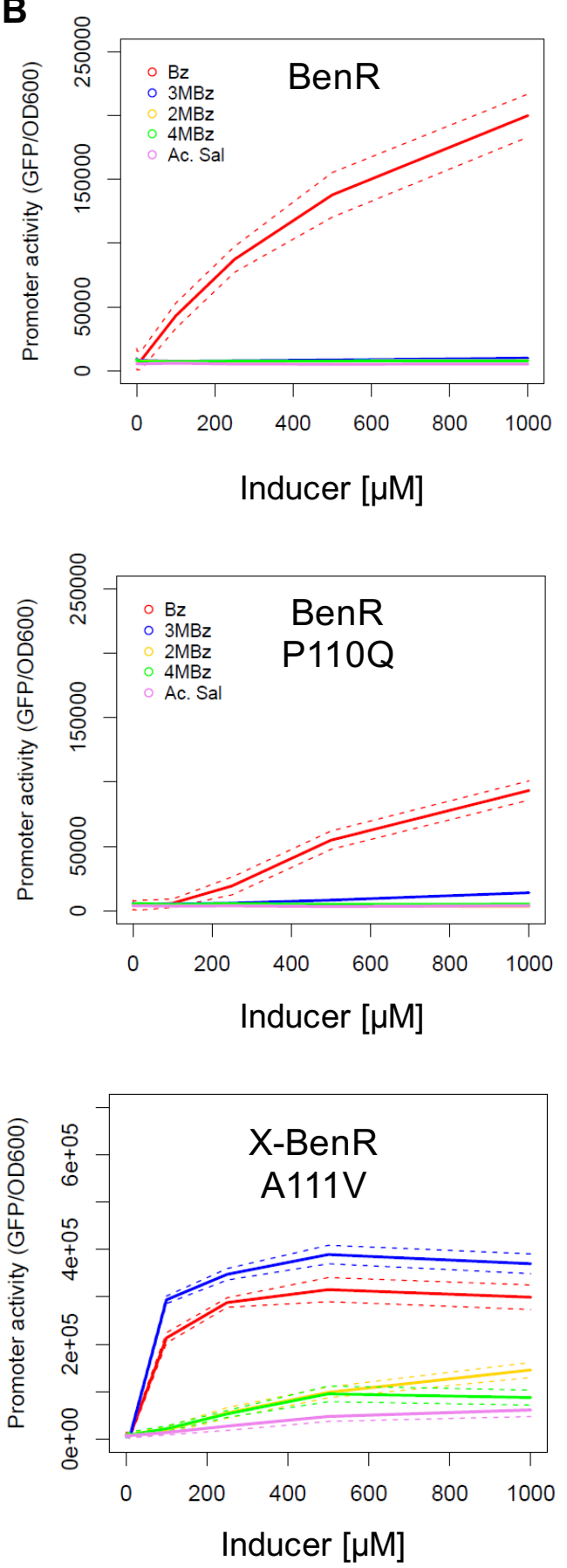
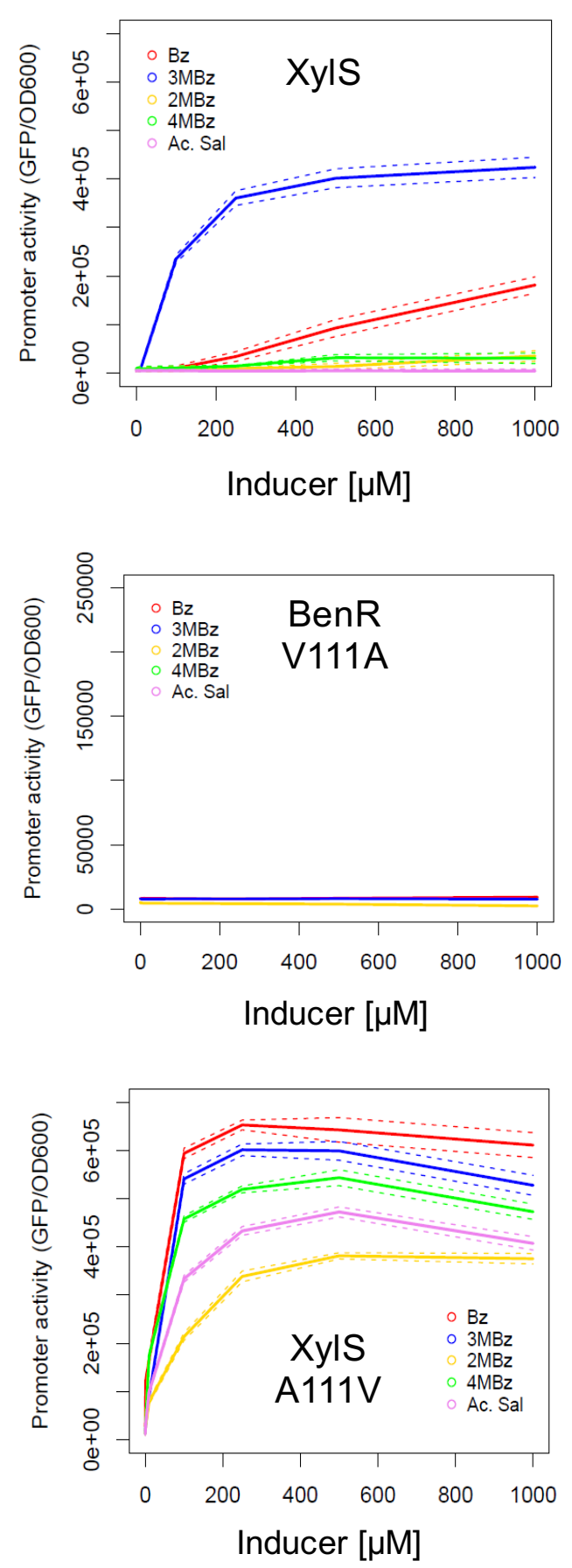
Bonzoic acid 3 methylbenzoic acid
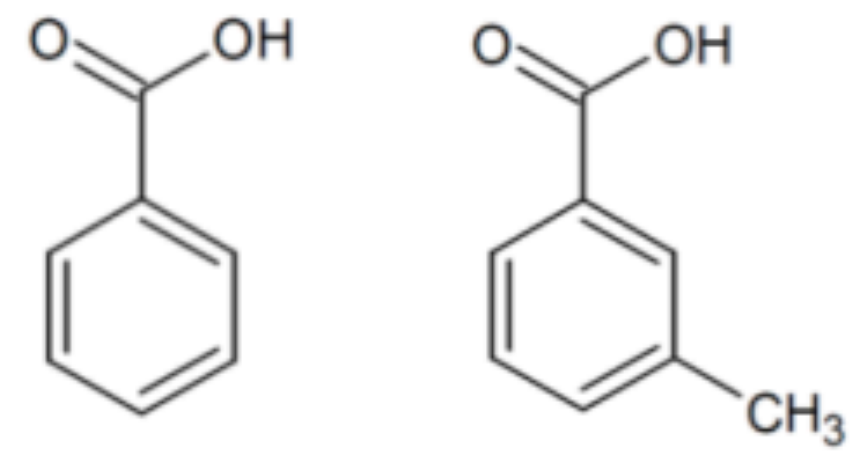

2 methylbenzoic acid

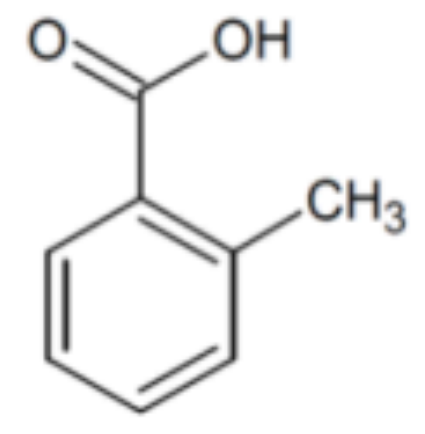

4 methylbenzoic<smiles>Cc1ccc(C(=O)O)cc1</smiles>

Salicylic acid

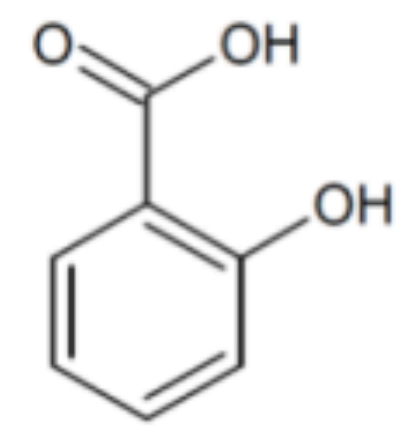

Acetylsalicylic acid

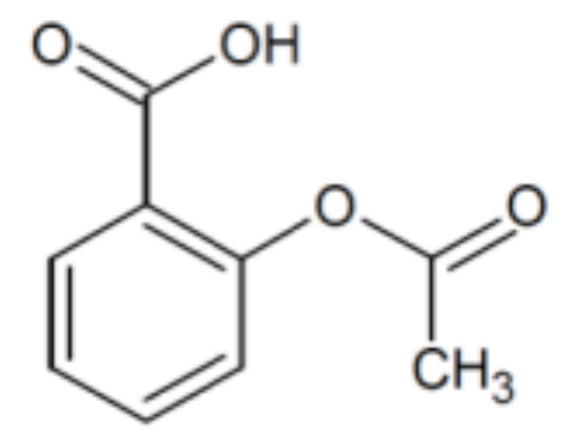

B

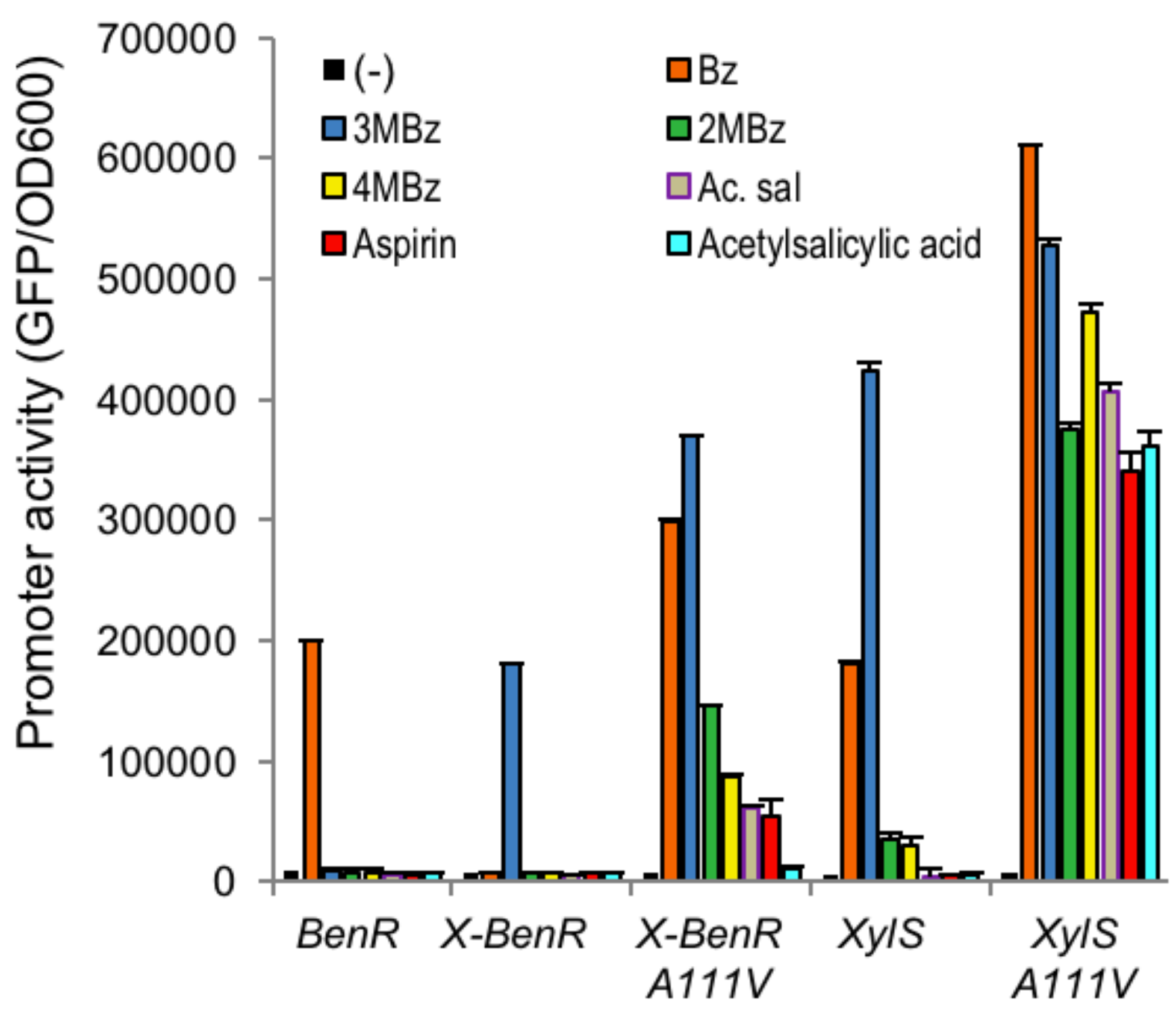

C

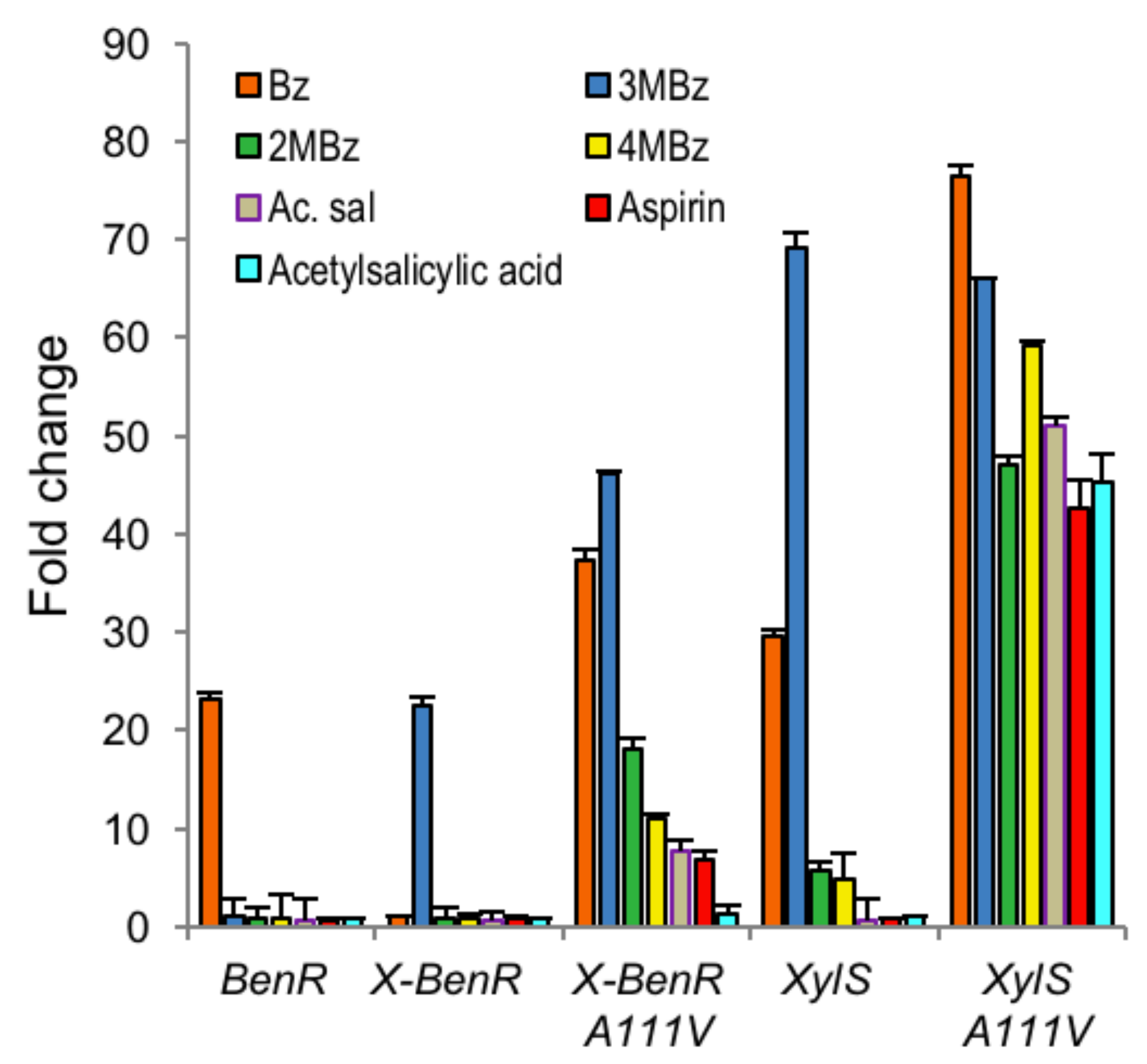

